\title{
PENGEMBANGAN MODEL PRODUKTIVITAS TANAH WAKAF UNTUK PEMBANGUNAN GEDUNG KOMERSIAL BERBASIS BUILD OPERATE TRANSFER (BOT)
}

\section{DEVELOPMENT OF LAND PRODUCTIVITY MODEL FOR COMMERCIAL BUILDING DEVELOPMENT BASED ON BUILD OPERATE TRANSFER (BOT)}

\author{
Saddam Husein, Martin \\ Roestamy, dan Achmad Jaka \\ Santos Adiwijaya
}

\author{
Magister Hukum Sekolah Pascasarjana, \\ Universitas Djuanda Bogor. \\ Korespondensi : Saddam Husein, Telp. \\ e-mail : saddam.husein@unida.ac.id
}

Jurnal

Living Law,

Vol. 13, No.

1,

2021

hlm. 11-19

\begin{abstract}
Almost all wakifs who surrendered their land to Nazhir did not include funds to finance productive business operations, this of course became a serious problem and obstacle in managing their waqf. This research was conducted with juridical normative, taking into account the existing provisions as well as provisions related to BOT or the practice of BOT agreement models with a case study approach and methods, meaning that this research was conducted to see what the expectations of legal products are in terms of this is about waqf and how it is in reality in the field so that the materials found in the field can be used as tertiary legal materials in order to develop which one is better than alternative solutions. The result of this research is to produce a modelwaqf land productivity based on BOT and it is hoped that it can be known and become a model that is believed by everyone who wants waqf.
\end{abstract}

Keywords : Waqf Land; Productive; Build Operate Transfer.

\begin{abstract}
Abstrak : Tujuan penelitian: 1) untuk mengetahui dan menganalisa pengembangan produktivitas tanah wakaf dengan prinsip pembiayaan syariah di Indonesia. 2) untuk mengetahui dan menganalisa proses produktivitas tanah wakaf dengan model Build Operate Transfer (BOT). Metode penelitian : dengan menggunakan analisis yuridis normatif dengan pendekatan kualitatif mengkombinasikan bahan hukum sekunder dengan bahan hukum primer sehingga menghasilkan analisis fakta yang terjadi dilapangan sebagai bahan hukum tersier. Hasil penelitian : 1) melihat apa yang menjadi harapan prodak hukum dalam hal ini mengenai wakaf sudah sesuai dengan praktek lapangan mana yang lebih baik dari arternatif solusi. 2) menghasilkan model produktifitas tanah wakaf berbasis Build Operate Transfer (BOT).
\end{abstract}

Kata Kunci : tanah wakaf; produktivitas; build operate transfer.

\section{PENDAHULUAN}

Tujuan Negara Kesatuan Republik Indonesia sebagaimana diamanatkan dalam pembukaan UUD 1945 antara lain adalah mensejahterakan kehidupan masyarakat. Demi mencapai tujuan tersebut diantara langkah strategis adalah memajukan potensi wakaf sebagai icon umat islam yang mempunyai kekuatan ekonomi yang berpotensi antara lain untuk memajukan ekonomi umat sehingga perlu di kembangkan pemanfaatannya secara produktif seperti membangun gedunggedung kemersial, shopping canter, pembangunan perumahan, fasiltas olahraga dengan prinsip pembiayaan syari'ah.

Pemanfaatan sumber daya alam seperti tanah dilaksanakan berdasarkan pada 
amanat konstitusi yang termuat dalam Pasal 33 ayat (3) UUD 1945 menyebutkan bahwa "bumi. Air dan kekayaan alam yang terkandung di dalamnya dikuasai oleh negara dan dipergunakan untuk sebesarbesarnya kemakmuran rakyat"

Kemudian selanjutnya Undang-Undang Nomor 5 Tahun 1960 tentang pokok-pokok agraria sebagai sumber hukum formil dan materil payung hukum dari hukum tanah dan segala yang berhubungan dengan tanah termasuk tanah wakaf ditindaklanjuti oleh berbagai peraturan diantaranya PP no. 28 tahun 1977 tentang perwakafan tanah milik, Impres no. 1 tahun 1991 tentang kompilasi hukum islam, UU no. 41 tahun 2004 tentang wakaf, PP no. 42 tahun 2006 tentang pelaksanaan UU no. 41 tahun 2004.

Perbuatan wakaf sebagai icon umat islam memberikan makna shodaqoh jariyah sebagaimana hadits dari abu hurairah R.a ; apabila seseorang hamba telah tutup usianya, maka terhalang semua amalnya selain hal-hal berikut; shodaqoh yang diterima Allah, ilmu yang diajarkan, dan doa anak yang sholeh. (HR. Muslim) ${ }^{1}$.

Bersumber dari data Departemen Agama dan Badan Wakaf Indonesia (BWI) tahun 2007, tanah wakaf luasnya mencapai 2.686.536.565,68 M2 (2,7 Milyar M2) tersebar di 466.595 lokasi. Potensi tersebut masih perlu dipetakan dan di inventarisir ${ }^{2}$. Dari total tanah wakaf yang ada, peruntukannya di dominasi wakaf fisik yang bersifat sosial, diantaranya $68 \%$ digunakan untuk tempat ibadah, 8,51\% untuk pendidikan, 8,40\% untuk kuburan dan $14,60 \%$ untuk lain-lain.

Wakaf di Indonesia lebih banyak dikelola oleh perseorangan 66\%, Organisasi kemasyarakatan 16\%, dan badan hukum 18\%. Harta wakaf juga lebih

1 Lihat Kitab Shahih Muslim No. 1631

2 Tito Murbaintoro, Potensi instrument pembiayaan dan wakaf pembangunan perumahan dan permukiman, seminar sehari potensi wakaf untuk bidang perumahan rakyat kerjasama kemenpera dan masyarakat ekonomi syariah deputi menpera bidang pembiayaan, jakarta 24 juni 2009, HIm. 18 banyak yang tidak menghasilkan $77 \%$ daripada yang menghasilkan atau produktif $23 \%$. Temuan lainnya benda wakaf lebih banyak berada diwilayah pedesan 59\% daripada perkotaan $41 \%{ }^{3}$

Berdasarkan jumlah tanah wakaf di atas ini, semestinya wakaf bisa dipergunakan untuk membiayai pembangunan masyarakat melalui berbagai kegiatan produktif seperti perbaikan kehidupan masyarkat miskin dimana menurut data badan statistik (BPS) menyebutkan penduduk dengan ekonomi rendah di Indonesia per maret 2017 mencapai $10,64 \%$ atau 27,77 juta jiwa, meningkatkan partisipasi publik, dan pembuatan kebijakan yang memuat golongan lemah.

Berdasarkan data departemen agama diatas peruntukan tanah wakaf untuk kepentingan produktif masih menunjukkan nilai yang cukup sedikit padahal amanah dari undang-undang wakaf tanah wakaf tidak hanya untuk penggunaan yang bersifat konsumtif namun diarahkan untuk kepentingan produktif dengan tujuan menjaga keabadian aset wakaf, menjadi lapangan pekerjaan, mengurangi beban anggaran negara, sebagai sumber dana untuk pembiayaan sosial keagamaan, lembaga pendidikan islam. dalam hal ini nazhir sebagai orang yang diamanahi dalam pengelolaan wakaf perlu meningkatkan kemampuan diri yaitu dengan memberikan pendidikan dan pembinaan.

Nazhir dalam perundang-undangan wakaf terdiri dari Nazhir Perorangan, Nazhir Organisasi, dan Nazhir badan hukum ketiga macam Nazhir tersebut memiliki kewenangan dalam pengelolaan tanah wakaf, banyak pewakaf yang mewakafkan tanahnya kepada Nazhir tidak memberikan dana untuk membiayai operasional keberlangsungan tanah wakaf tersebut khsususnya dalam bidang usaha produktifitas tanah wakaf. Hal ini juga tentu menjadi masalah dan hambatan

\footnotetext{
${ }^{3}$ Ibid. Hlm. 19
} 
dalam rencana produktifitas tanah wakaf sehingga dibutuhkan strategi riil yang harus dilakukan Nazhir dalam upaya produktifitasnya.

Salah satu produktifitas tanah wakaf yang diperbolehkan undang-undang adalah dengan cara investasi atau kerjasama dengan pihak ketiga, cara investasi ini cukup menjamin bagi kelangsungan kemanfaatan tanah wakaf, cara kerjasama ini sejalan dengan cara yang di lakukan oleh tabung wakaf Indonesia (TWI) sebagai Nazhir wakaf dengan mendirikan gedung futsal diatas tanah wakaf seluas 845 meter persegi, pembiayaan pembangunan gedung futsal ini bersumber dari bantuan pihak ketiga, gedung futsal tersebut di sewakan kepada pecinta sepakbola yang berasal dari kalangan siswa, mahasiswa, dan pemudapemuda di wilayah tersebut ${ }^{4}$.

Gedung futsal diatas tanah wakaf ${ }^{5}$ yang berlokasi di Jl. Haji Musa, Pondol Ranji, Tangerang selatan ini biasanya penyewa lapangan membayar $60 \mathrm{ribu}, 100 \mathrm{ribu}$, bahkan sampe 120 ribu per satu jam nya, dari hasil penyewaan tersebut setiap bulannya pengelola mendapatkan pemasukan 17 juta hingga 21 juta perbulannya dan merupakan penghasilan bersih setelah dikurangi biaya operasional.

Salain pemasukan dari penyewaan lapangan futsal, tanah dan gedung wakaf ini juga mendapat penghasilan sampingan dari penyewaan lokasi untuk ATM bank. Setiap tahunnya mendapat pemasukan sebesar 33 juta. Pihak Nazhir Dompet Dhuafa menyalurkan surplus wakaf ini dalam bentuk program beasiswa bagi SMPSMA yang berlokasi di Jl. Raya parung Bogor KM. 42, Ds. Jampang, Kec. Kemang, Kab. Bogor, Jawa Barat.

Di seluruh dunia wakaf produktif sudah menjadi pradigma utama dalam

${ }^{4}$ (https://www.bwi.go.id/1351/2015/08/artikel/in spirasi-wakaf/dari-sepakbola-untukpendidikan/ di akses 01 Agustus 2020 jam 10.00)

${ }^{5}$ (https://www.bwi.go.id/1351/2015/08/artikel/in spirasi-wakaf/dari-sepakbola-untukpendidikan/ di akses 01 Agustus 2020 jam 10.00) mengelola aset. Sebut saja mesir, aljazair, sudan, kuwait, dan tuki mereka jauh-jauh hari sudah mengelola wakaf ke arah produktif. Sebagai contoh Majelis Ugama Islam Singapura berijtihad mendirikan waress Investmen Pte Ltd sebagai anak perusahaan yang dibentuk untuk tujuan pemisahan fungsi komersial dalam mengelola dan membangun tanah wakaf. Pembentukan perusahaan ini sangat diperukan karena portfolio ${ }^{6}$. waress Investmen telah berhasil dalam mengelola aset wakaf sejak awal berdiri sampai 2013 sedikitnya telah mampu mengelola 155 aset wakaf yang ada.

Salah satu bentuk produktifitas tanah wakaf yang masih jarang ditemukan di Indonesia adalah bangunan gedung berlantai atau perumahan untuk kebutuhan tempat tinggal bagi masyarakat khususnya masyarakat berpenghasilan rendah dimana gedung atau perumahan tersebut bisa disewakan seperti yang di contohkan oleh negara singapura disisi lain tempat tinggal adalah kebutuhan mendasar bagi manusia. ${ }^{7}$

Salah satu bentuk produktifitas tanah wakaf seperti yang di contohkan oleh Badan Wakaf Indonesia (BWI) di kawasan Rasuna said bisa dilakukan dengan sistem perjanjian Build Operate Transfer (BOT). Build Operate Transfer (BOT) adalah bentuk perjanjian antara pemilik tanah dengan pemilik dana, dimana pihak pemilik tanah menyerahkan tanahnya kepada pemilik dana untuk dibangun gedung dalam jangka waktu yang telah disepakati kemudian pihak pemilik dana memberikan bangun gedung kepada pihak pemilik tanah kembali ${ }^{8}$.

6 Portfolio adalah kumpulan dari instrumen investasi yang dibentuk untuk memenuhi suatu sasaran umum investasi.

7 Martin Roesrtamy, Providing Affordable Housing For Low-Income People In Indonesia (Development Of Model On Housing Law), Jurnal IJASOS- International E-Journal of Advances in Social Sciences, Vol. III, Issue 9, December 2017, Hlm.1096

8 Urip Santoso "Kewenangan Pemerintahan Daerah Terhadap Hak Penguasaan Atas Tanah" 
Dengan melihat kondisi tersebut maka penulis memandang perlunya sebuah kajian mendalam yang dapat menjawab mengenai berbagai persoalan dalam pengembangan produktifitas tanah wakaf untuk pembangunan gedung komersial khususnya dengan menarapkan sistem BOT. Sehingga berdasarkan uraian diatas maka penulis merumuskan dua identifikasi masalah sebagai berikut :

1. Bagaimana pengembangan produktifitas tanah wakaf dengan prinsip pembiayaan syariah di Indonesia?

2. Bagaimana proses produktifitas tanah wakaf dengan model build operate transfer (BOT)?

\section{METODE PENELITIAN}

Metode penelitian yang digunakan untuk penelitian ini yaitu dengan menggunakan analisis yuridis normatif dengan pendekatan kualitatif mengkombinasikan bahan hukum sekunder dengan bahan hukum primer sehingga menggambarkan suatu kebijakan yang terkait dengan wakaf selanjutnya dilakukan pengkajian apakah pemberlakuannya sesuai dengan ketentuan-ketentuan normatif dengan pendekatan peraturan-peraturan, konsep, dan History ${ }^{9}$.

Teknik pengumpulan data yang dilakukan dengan cara penelitian kepustakaan dengan mencari dan mengumpulkan serta meneliti bahan pustaka yang merukan bahan sekunder. Dari data sekunder tersebut dikombinasikan dengan contoh model yang ada dilapangan serta keterangan para pihak yang terkait.

Adapun yang menjadi bahan pengumpulan data ialah sebagai berikut

dalam Maria S.W. Sumardjono, 2008, Tanah Dalam Perspektif Hak Ekonomi, Sosial, dan Budaya, Jakarta: Penerbit Buku Kompas, Hlm. 208

9 Martin Roestamy et al, Metode Penelitian dan Penulisan Hukum, Unida Press, Bogor, 2015, Hlm. 49
1. Bahan hukum primer seperti peraturan perundang-undangan yang berkaitan dengan wakaf.

2. Bahan hukum sekunder yaitu kepustakaan tentang model produktifitas tanah wakaf denga cara kerjasama, dapat juga dilihat dari hasil penelitian atau artikel jurnal yang berkaitan, dari itu maka dikombinasikan antara data sekunder dengan data primer.

Penelitian ini diolah menggunakan analisis data yang berupa analisis kualitatif dengan mengkaji sekaligus menguraikan sumber-sumber data dengan menggunakan deskripsi tiga tahapan yaitu pertama mengumpulkan data primer, skunder dan tersier. Setelah itu tahap kedua penyajian, penelaahan dan pengolahan data. Yang terakhir yaitu menarik kesimpulan dengan metode deduktif - induktif.

\section{PEMBAHASAN}

\section{A. DINAMIKA PENGELOLAAN WAKAF DARI NAZHIR PERORANGAN KEPADA NAZHIR BADAN HUKUM}

Dinamika pemberdayaan wakaf di Indonesia dibagi kepada tiga fase : Fase pertama dikenal dengan fase non profesional, yaitu tanah wakaf dipergunakan kepada benda tidak bergerak separti untuk pemakaman umum, masjid, musolla, dan madrasah. Pada fase ini proses penyerahan wakaf dilakukan secara ucapan saja kepada pihak yang diamanahkan menerima wakaf tanpa dilakukan pencatatan. Di dalam fase ini sangat memungkinkan terjadinya kehilangan tanah wakaf ${ }^{10}$.

Fase kedua dikenal dengan fase semi profesional di dalam fase ini pemberdayaan tanah wakaf mulai dilakukan kearah produktif, namun belum secara penuh, di dalam fase ini penyerahan wakaf dilakukan secara resmi dengan dilakukan pencatatan

\footnotetext{
10 Ibid. Hlm. 82
} 
di hadapan pejabat yang berwenang sehingga memiliki kekuatan secara hukum.

Fase ketiga dikenal dengan fase profesional dimana tanah wakaf dikembangkan secara produktif. Produktif adalah bentuk perwakafan yang dapat mendatangkan nilai ekonomis. Hal ini dapat di lihat dalam Undang-undang tentang wakaf dengan demikian perwakafan di Indonesia telah memasuki fase profesional ${ }^{11}$.

\section{B. MODEL PENGEMBANGAN PRODUKTIVITAS TANAH WAKAF DENGAN PRINSIP PEMBIAYAAN SYARI'AH DI INDONESIA.}

Beberapa model pembiayaan yang dapat ditarapkan dalam pembiayaan wakaf tanah, yaitu:

\section{Murabahah}

Dalam pembiayaan wakaf tanah produktif Nazhir dapat membuat perjanjian dengan pihak pertama sebagai pemilik modal (Shohibul mal) kemudian nazhir sebagai pengelola membelanjakan uang tersebut kepada bahan bahan untuk pembangunan gedung komersial selanjutnya nazhir mengembalikan modal tersebut dengan cara mencicil12.

\section{Istishna'}

Model Istishna' Model ini memungkinkan pengelolaan tanah wakaf untuk memesan pengembangan harta wakaf yang diperlukan kepada lembaga pembiayaan melalui suatu kontrak Istishna. Lembaha pembiayaan atau bank kemudian membuat kontrak dengan kontraktor untuk memenuhi pesanan pengelola harta wakaf atas nama lembaga pembiayaan itu. Model pembiayaan istishna juga menimbulkan hutang bagi pengelola harta wakaf dan dapat diselesaikan dari hasil pengembangan harta wakaf dan penyedia

11 Ibid. HIm. 83

12 Riva'I, Veithzal \& Andria Permata Veithzal, Islamic Financial Management, Teori, Konsep dan Aplikasi Praktis untuk Lembaga Keuangan, Nasabah, Praktisi dan Mahasiswa, Jakarta, Rajawali 2008. pembiayaan tidak mempunyai hak untuk turut campur dalam pengelolaan harta wakaf ${ }^{13}$.

3. Ijarah

Ijarah, melalui pembiayaan ijarah LKS dan /atau Nazhir yang ditunjuk dapat mendayagunakan harta benda wakaf yang kurang produktif, baik dalam bentuk tanah maupun bangunan. Berkaitan dengan itu LKS menyediakan dana untuk mengelola harta benda wakaf. Kemudian menyewakannya hingga dapat menutupi modal pokok dan mengambil keuntungan. Apabilla masa pembayaran sewa telah selesai maka kepemilikan bangunan tersebut berpindah milik dari penyedia dana kepada nazhir wakaf tanah tersebut ${ }^{14}$

\section{Mudharabah}

Ada dua jenis mudharabah yang dapat ditarapkan dalam pembiayaan wakaf tanah, yaitu : mudharabah berbasis aset dan mudharabah berbasis modal uang.

a. Mudharabah berbasis aset. Pengelola wakaf dapat mempersilahkan penyedia dana untuk membangun gedung diatas tanah wakaf. Bangunan yang selesai didirikan selanjutnya disewakan kepada pihak ketiga. Hasil dari penyewaan tersebut dibagi dua antara pengelola wakaf dan penyedia dana. Pengelola wakaf harus membagi keuntungan yang diperolehnya pada dua hal, yaitu untuk meningkatkan saham kepemilikan pada gedung tersebut dan penerima manfaat wakaf (mauquf'alaih).

b. Mudharabah berbasis modal kapital. Menurut munzer kahf, model mudharabah dapat digunakan apabila nazhir memposisikan dirinya sebagai pengusaha. Ia dapat menerima dana cair dari institusi keuangan untuk membangun gedung diatas tanah wakaf. Pengelolaan wakaf berada

13 Ascarya, Akad \& Produk Bank Syariah, Rajawali Press, Jakarta, 2007,Hlm. 96.

14 Direktorat Pemberdayaan Wakaf, Model Pengembangan Wakaf Produktif, Jakarta, Direktorat Pemberdayaan Wakaf, 2008, Hlm. 82. 
ditangan nazhir dan rasio bagi hasil dapat disepakati menurut pertimbangan usaha yang dilakukan oleh pengelola dan kepemilikan tanah wakaf yang digunakan ${ }^{15}$.

\section{Musyarakah}

Musyarakah adalah akad kerjasama antara dua pihak atau lebih untuk suatu usaha tertentu, dimana masing-masing pihak memberikan kontribusi dana dengan ketentuan bahwa keuntungan dibagi berdasarkan sedangkan kerugian berdasarkan porsi kontribusi dana berupa kas maupun aset non-kas yang diperkenankan oleh syariah ${ }^{16}$.

Lembaga wakaf dan bank dapat melakukan kerjasama pembangunan gedung, bank menyediakan dana sedangkan lembaga wakaf menyediakan tanah, maka keuntungan dibagi dua. Pertama untuk mengembalikan dana dari bank, kedua dibagi antara lembaga wakaf dan bank.

\section{PENGEMBANGAN PRODUKTIFITAS TANAH WAKAF DENGAN MODEL BUILD OPERATE TRANFER (BOT)}

Definisi BOT sebagaimana disampaikan Anita Kamilah adalah perjanjian antara dua pihak, dimana pihak pertama menyerahkan penggunaan tanahnya untuk didirikan suatu bangunan diatasnya oleh pihak kedua, dan pihak kedua berhak mengoperasikan atau mengelola bangunan tersebut dalam jangka waktu tertentu, dan pihak kedua wajib mengembalikan tanah beserta bangunan diatasnya setelah jangka waktu operasional berkahir ${ }^{17}$.

Di indonesia penggunaan pola BOT untuk investasi tanah wakaf belum banyak dikenal dan dilakukan untuk proyek

15 Kahf, Kahf, Monzer, al-Waqf al-Islamy, Tathwuruh, Idāratuh, Tanmiyyatuh, Dār al-Fikr, Suriah, 2006, Hlm. 16.

16 Riva'I, Of. Cit, Hml. 45

17 Maria SW Sumardjono, Tanah dalam Perspektip Hak Ekonomi Sosial dan Budaya. Kompas Jakarta, Januari 2008. HIm 208 infrastruktur berupa gedung-gedung komersial di antaranya :

Gedung Raudha milik Yayasan Raudhatul Muta'allimin (YRM) ${ }^{18}$ penjelasan pengurus yayasan bidang pendidikan, (YRM) dapat menghasilkan Rp. 900 juta per tahun dari penyewaan Gedung Raudha tersebut. Hasil penyewaan ini merupakan dana operasional yang digunakan sehingga YRM berkembang. Ada banyak perusahaan swasta berkantor di Gedung tersebut.

Bangunan Gedung tersebut didirikan diatas tanah bersertifikat wakaf atan nama Nazhir badan hukum Yayasan Raudhatul Muta'allimin. Letaknya tidak sampai $1 \mathrm{Km}$ dari lampu merah mampang.

Yayasan yang didirikan sejak 1945 ini memulai pembanguana gedung dengan dana sendiri namun tidak selesai, selanjutnya pihak yayasan melakukan kerjasama dalam penyelesaian gedung sehingga terselesaikan pada tahun 2010 sebagai kompensasinya pihak investor mendapat laba dari penyewaan gedung tersebut selama jangka waktu yang disepakati setelah jangka waktu berakhir Nazhir YRM mengelola sendiri gedung tersebut.

Dari pengelolaan gedung secara mandiri YRM mendapat keuntugan 900juta per tahun, Bahkan semua siswa kelas 1 RA, MI dan MTs mendapat beasiswa biaya sekolah. Belajar dari kerjasama gedung Raudha Nazhir YRM kemudian bekerjasama kembali dengan investor lain pada 2013 untuk membangun gedung perkantoran komersial. Tetapi lebih tinggi dan lebih besar. Luas tanah yang dikerjasamakan lebih kurang 4.000 M2.

Kerjasama ini menggunakan skema Build Operate Transfer (BOT). Investor membiayai pembangunan gedung, menggunakan selama 35 tahun, lalu setelah itu menyerahkan kepemilikan gedung dan pengeolalaannya kepada Nazhir.

\footnotetext{
18https://www.bwi.go.id/1356/2015/09/artikel/in spirasi-wakaf/berkat-investor-wakaf-inihasilkan-lebih-dari-rp1-m/ Artikel Online di akses 20 Agustus 2020 jam 10.00 Wib.
} 
Kompensasi lainnya Nazhir memperoleh uang sewa Rp 1.2 miliar per tahun. Nilai sewa pun bertambah setiap tahun mengikuti laju inflasi. Meski hingga kini gedung belum berdiri, Nazhir sudah menerima pembayaran sebanyak empat kai setiap enam bulan.

Dengan berhasilnya proses produktifitas tanah wakaf maka manfaat wakaf semakin terasa bagi masyarakat khususnya dibidang pendidikan dan ekonomi. Gaji pokok Guru naik drastis, dari Rp 1 jutaan menjadi Rp 2 jutaan. Bahkan kini mereka juga memperoleh tunjangan asuransi jaminan hari tua. Salain itu, YRM bisa membangun laboratorium bahasa, laboratorium IPA, ruang perpustakaan, dan ruang kelas baru tiga lantai.

Perlunya rekonstruksi konsep fiqih wakaf, diamati oleh Uswatun Hasanah di dasarkan salah satunya pada pengelolaan wakaf di Indonesia yang sangat memperhatinkan. Ia menunjukkan bahwa wakaf, banyaknya yayasan pendidikan yang bersumber dari tanah wakaf menjadi terlantar, tidak berkembang bahkan gulung tikar dengan adanya wakaf produktif diharapkan menajadi solusi dalam permasalahan ini.

Didirikannya bangunan gedung di atas tanah wakaf yang diorentasikan penggunaan dan kemanfaatannya untuk memperoleh keuntungan, seperti hotel, gedung perkantoran, residensial, maupun area komersial lainnya merupakan upaya bentuk pengembangan wakaf produktif. Dengan penerapan teori ijtihad wakaf, ijtihad insya'i yaitu pengembalian konklusif hukum baru dari satu persoalan yang belum pernah dikemukakan oleh ulama terdahulu. Atau langkah mujtahid kontemporer untuk mempunyai pemahaman baru dalam masalah itu yang belum diperoleh dalam pendapat ulamaulama salaf, baik itu persoalan lama atau persoalan baru.

Menjadi solusi pemecahan masalah untuk mengatur kepemilikan tanah oleh Nazhir yang dipisahkan dari kepemilikan bangunan gedung oleh individu-individu masing-masing, sebagaimana yang telah dicontohkan oleh negara singapore dan Dubai.

\section{KESIMPULAN}

1. Pengembangan model produktifitas tanah wakaf untuk pembangunan commercial building dengan prinsip pembiayaan syari'at dapat dilakukan dan juga merupakan salah satu model pengelolaan wakaf yang menguntungkan secara ekonomi, dan merupakan salah satu bentuk pengembangan pengelolaan tanah wakaf yang dapat dilakukan berdasarkan undang-undang wakaf. Dalam pelaksanaan produktifitas tanah wakaf dengan pembiayaan syari'at bisa dilakukan dengan model pembiayaan Murabahah, Istishna, Ijarah, Mudharabah, dan Musyarakah dimana hasil dari pembiayaan produktifitas tanah wakaf tersebut dapat dimanfaatkan untuk beasiswa pendidikan seperti yang dilakukan oleh Tabung Wakaf Indonesia (TWI) Dhompet Dhu'afa sebagai Nazhir, pinjaman atau pemberian modal usaha produktif untuk masyarakat ekonomi rendah, dan meningkatkan kesejahteraan masyarakat, khususnya model pembiayaan tanah untuk pembangunan gedung-gedung komersial.

2. Proses produktifitas tanah wakaf dengan model Build Operate Transfer (BOT) sesuai dengan teori Ijtihad (penemuan baru) yang dikemukakan oleh yusuf Qardhawi merupakan salah satu solusi model produktifitas tanah wakaf untuk pembangunan gedung komersial di atas tanah wakaf dimaksudkan agar tanah wakaf dapat dikelola dengan baik, proses produktifitas tanah wakaf dengan model BOT tersebut dapat dilakukan melalui Nazhir wakaf berbentuk badan hukum yang menjalin kerjasama pemanfaatan tanah wakaf di Indonesia. 
Wakaf tanah dikelola dan dikembangkan secara operasional oleh Nazhir badan hukum yang diawasi oleh organ yayasan dan mengatur hubungan Nazhir secara hukum perdata dalam bentuk perjanjianperjanjian tertentu dengan investor BOT maupun dengan end-user atau pengguna hasil kerjasama BOT. Berupa kawasan komersial antara lain perkantoran, shopping canter, pembangunan perumahan, fasilitas olahraga. Dengan ikrar wakaf dan perjanjian keperdataan seperti sewa menyewa atau sewa beli atas gedung maupun unit-unit dari gedung.

\section{SARAN}

1. Model produktifitas tanah wakaf untuk pembangunan gedung komersial yang berdiri di atas tanah wakaf belum banyak dilakukan di Indonesia dibandingkan beberapa negara yang berhasil mengembangkan tanah wakaf melalui pembangunan gedung komersial, seperti Singapura, Malaysia dan sebagainya. Indonesia melalui kementrian Agama dan Badan Wakaf Indonesia lebih fokus dan serius lagi memberikan perhatian, pemahaman kepada wakif dan masyarakat sehingga dipercaya oleh masyarakat yang ingin berwakaf terkait wakaf tanah produktif dengan model prinsip pembiayaan syari'ah

2. Kementrian Agama dan Badan Wakaf Indonesia memberikan usulan kepada presiden terkait model BOT produktifitas tanah wakaf untuk dijadikan salah satu model utama dan model yang memiliki kekuatan hukum yang bisa dipake dengan aman oleh Nazhir dalam upaya memproduktifkan tanah wakaf kemudia Kementrian Agama dan Badan Wakaf Indonesia secara intensif memberikan pembinaan khusus terhadap Nazhir dalam praktek produktifitas tanah wakaf dengan model BOT ini. Keberhasilan beberapa Nazhir dalam produktifitas tanah wakaf untuk membangun gedung komersial berbasis BOT bisa dijadikan sebagai contoh yang baik untuk di ikuti. Kerana dalam pelaksanaan perjanjian BOT memberikan keuntungan bagi kedua belah pihak baik, pada saat pembangunan, pengoperasian, dan pada saat penyerahan bangunan.

\section{DAFTAR PUSTAKA}

Abdurrohman Kasdi, Pergeseran Makna Dan Pemberdayaan Wakaf (dari Konsumtif ke Produktif).

Ascarya, Akad \& Produk Bank Syariah, Rajawali Press, Jakarta, 2007.

Anita Kamilah, Bangun Guna Serah (Build Operate transfer) Membangun tanpa harus memiliki tanah (Perspektif hukum agraria, Hukum Perjanjian dan hukum Publik), Keni Media, 2012.

Direktorat Pemberdayaan Wakaf, Model Pengembangan Wakaf Produktif, Jakarta, Direktorat Pemberdayaan Wakaf, 2008.

Lihat Kitab Shahih Muslim No. 1631 
Martin Roestamy, Providing Affordable Housing For Low-Income People In Indonesia (Development Of Model On Housing Law), Jurnal IJASOS-International E-Journal of Advances in Social Sciences, Vol. III, Issue 9, December 2017.

Martin Roestamy et al, Metode Penelitian dan Penulisan Hukum, Unida Press, Bogor, 2015.

Monzer Kahf,, al-Waqf al-Islamy, Tathwuruh, Idāratuh, Tanmiyyatuh, Dār al-Fikr, Suriah, 2006.

Riva'I, Veithzal \& Andria Permata Veithzal, Islamic Financial Management, Teori, Konsep dan Aplikasi Praktis untuk Lembaga Keuangan, Nasabah, Praktisi dan Mahasiswa, Jakarta, Rajawali 2008.

Tito Murbaintoro, Potensi instrument pembiayaan dan wakaf pembangunan perumahan dan permukiman, seminar sehari potensi wakaf untuk bidang perumahan rakyat kerjasama kemenpera dan masyarakat ekonomi syariah deputi menpera bidang pembiayaan, jakarta 24 juni 2009.

Urip Santoso "Kewenangan Pemerintahan Daerah Terhadap Hak Penguasaan Atas Tanah" dalam Maria S.W. Sumardjono, Tanah Dalam Perspektif Hak Ekonomi, Sosial, dan Budaya, Jakarta: Penerbit Buku Kompas, 2008.

https://www.bwi.go.id/1351/2015/08/artikel/inspirasi-wakaf/dari-sepakbola-untukpendidikan/ di akses 01 Agustus 2020 jam 10.00

https://www.bwi.go.id/1351/2015/08/artikel/inspirasi-wakaf/dari-sepakbola-untukpendidikan/ di akses 01 Agustus 2020 jam 10.00

https://www.bwi.go.id/1356/2015/09/artikel/inspirasi-wakaf/berkat-investor-wakafini-hasilkan-lebih-dari-rp1-m/ Artikel Online di akses 20 Agustus 2020 jam 10.00 Wib. 